\title{
Chemometric characterization of the hydrogen bonding complexes of secondary amides and aromatic hydrocarbons
}

\author{
Branislav Jović ${ }^{1}$, Aleksandar Nikolić ${ }^{1}$, Slobodan Petrović ${ }^{2}$ \\ ${ }^{1}$ University of Novi Sad, Department of Chemistry, Faculty of Sciences, Novi Sad, Serbia \\ ${ }^{2}$ University of Belgrade, Faculty of Technology and Metallurgy, Beograd, Serbia
}

\begin{abstract}
This paper reports the results of the study of hydrogen bonding complexes between secondary amides and various aromatic hydrocarbons. The possibility of using chemometric methods was investigated in order to characterize $\mathrm{N}-\mathrm{H} \cdots \pi$ hydrogen bonded complexes. Hierarchical clustering and Principal Component Analysis (PCA) have been applied on infrared spectroscopic and Taft parameters of $43 \mathrm{~N}$-substituted amide complexes with different aromatic hydrocarbons. The results obtained in this study are in good agreement with conclusions of other spectroscopic and thermodynamic analysis.
\end{abstract}

Keywords: hydrogen bonding; secondary amides; aromatic hydrocarbons; principal component.

\section{SCIENTIFIC PAPER}

UDC 547.52:547.39’054.4

Hem. Ind. 66 (1) 1-7 (2012)

doi: 10.2298/HEMIND110624058J

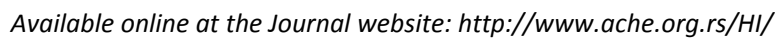

Hydrogen bonding of the amide group is an important factor that affects the structure of polypeptides and proteins. $\mathrm{N}$-substituted amides are the simplest model molecules having a peptide group, and consequently, many studies have been devoted to the hydrogen bonding of N-substituted amides [1-5]. It is also well known that aromatic hydrocarbons can act as the proton acceptors and participate in hydrogen bonding with various phenols and amines [6]. The knowledge of weak $\mathrm{N}-\mathrm{H} \cdots \pi$ interactions on the molecular level contributes to a better understanding of their possible role in many biological systems [7]. In our laboratory, during a continuous and extensive research of $\mathrm{N}$-substituted amides and their interactions in solutions, $\mathrm{N}-\mathrm{H} \cdots \pi$, complexes were investigated using IR technique [8-11]. Chemometric methods are successfully applied to various chemical data, including the spectroscopic ones [12-14]. Consequently, it seems reasonable and interesting to treat IR spectroscopic data of $\mathrm{N}-\mathrm{H}$ hydrogen bonds on the basis of chemometrics.

In this work, chemometric methods have been used for comparison of hydrogen-bonded complexes of different N-substituted amides with aromatic donors. Such chemometric identification has not been reported previously. We believe it can be useful in qualification of different hydrogen bonded systems. Principal component analysis (PCA) and hierarchical cluster analysis were applied in order to visualize multivariate spectroscopic data and to find relationships among variables.

Correspondence: B. Jović, Department of Chemistry, Faculty of Sciences, University of Novi Sad, Trg Dositeja Obradovića 3, 21000 Novi Sad, Serbia.

E-mail: branislav.jovic@dh.uns.ac.rs

Paper received: 24 June, 2011

Paper accepted: 4 August, 2011

\section{EXPERIMENTAL}

\section{Materials and methods}

Various $\mathrm{N}$-monosubstituted formamides, acetamides, and propionamides, of general formula HCONHR, $\mathrm{CH}_{3} \mathrm{CONHR}$, and $\mathrm{CH}_{3} \mathrm{CH}_{2} \mathrm{CONHR}$, wherein $\mathrm{R}$ is methyl, ethyl, $n$-butyl, sec-butyl, isobutyl, tert-butyl, cyclohexyl, were synthesised by Schotten-Baumann reaction of acylation of the corresponding amines with alkyl chloride $[15,16]$. The purity of these $\mathrm{N}$-monosubtituted amides was checked by GC and mass spectrometry. For all samples used in this work the purities were estimated to be $99.2 \%$ or better. The aromatic hydrocarbons were obtained from commercial sources (Frinton, Fluka, $>97 \%$ ) and have been used without further purification.

Hydrogen bonding parameters of investigated complexes are summarized in Table 1.

In order to avoid self-association, amide concentration in carbon tetrachloride solutions was below 0.003

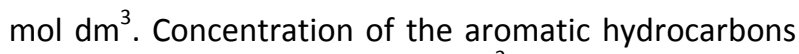
varied between 0.2 and $1 \mathrm{~mol} \mathrm{dm}^{-3}$.

Infrared spectra have been obtained using Bomem MB 100 FTIR spectrophotometer with $1 \mathrm{~cm}$ UVIRSIL cell and measurements have been performed at $298 \mathrm{~K}$. The reported frequencies and half-widths were reproducible within 0.2 and $1 \mathrm{~cm}^{-1}$, respectively. The integrated molar absorption coefficients were obtained within $\pm 5 \%$. The equilibrium constants were determined with average relative standard deviation of $6 \%$. The uncertainties in $\Delta H$ are within $\pm 0.25 \mathrm{~kJ} \mathrm{~mol}^{-1}$, respectively.

Deconvolution of the partially overlapped complex and free $v(\mathrm{NH})$ bands and calculation of spectroscopic variables $\left(\Delta v, v_{1 / 2}\right.$ and $\left.\mathrm{B}\right)$ was done using PeakFit software (Aspire Software International's, Ashburn, USA). The formation constants were determined from the 
Table 1. Hydrogen bonding parameters of investigated complexes

\begin{tabular}{|c|c|c|c|c|c|c|c|c|c|}
\hline Amide & No. & Electron donor & $\begin{array}{c}\Delta v \\
\mathrm{~cm}^{-1}\end{array}$ & $\begin{array}{c}v_{1 / 2} \\
\mathrm{~cm}^{-1}\end{array}$ & $\begin{array}{c}B^{\times} 10^{6} \\
\mathrm{~cm} \mathrm{~mol}^{-1}\end{array}$ & $\mathrm{dm}^{3} \mathrm{~mol}^{-1}$ & $\begin{array}{c}-\Delta H \\
\mathrm{KJ} \mathrm{mol}^{-1}\end{array}$ & $\Sigma \sigma$ & $\Sigma E s$ \\
\hline \multirow[t]{10}{*}{$N$-t-Butyl formamide } & 1 & Benzene & 23 & 20 & 5.14 & 0.26 & 5.0 & -0.79 & -2.78 \\
\hline & 2 & Toluene & 29 & 25 & 5.73 & 0.31 & 5.3 & -1.28 & -4.02 \\
\hline & 3 & Ethylbenzene & 30 & 25 & 5.89 & 0.33 & 5.5 & -1.38 & -4.09 \\
\hline & 4 & n-Propylbenzene & 30 & 26 & 5.98 & 0.33 & 5.5 & -1.4 & -4.38 \\
\hline & 5 & n-Butylbenzene & 31 & 26 & 6.07 & 0.35 & 5.5 & -1.41 & -4.41 \\
\hline & 6 & o-Xylene & 31 & 26 & 6.11 & 0.35 & 5.4 & -1.77 & -5.26 \\
\hline & 7 & Mesytilene & 38 & 31 & 6.82 & 0.43 & 6.0 & -2.26 & -6.5 \\
\hline & 8 & Durene & 42 & 34 & 7.35 & 0.50 & 6.2 & -2.75 & -7.74 \\
\hline & 9 & Pentamethylbenzene & 47 & 37 & 8.71 & 0.59 & 6.5 & -3.24 & -8.98 \\
\hline & 10 & Hexamethylbenzene & 50 & 39 & 9.05 & 0.67 & 6.7 & -3.73 & -10.22 \\
\hline \multirow[t]{5}{*}{$N$-Cyclohexyl formamide } & 11 & Benzene & 23 & 27 & 9.43 & 0.19 & 5.1 & -0.64 & -2.03 \\
\hline & 12 & Toluene & 28 & 30 & 10.93 & 0.26 & 5.3 & -1.13 & -3.27 \\
\hline & 13 & Ethylbenzene & 30 & 34 & 11.33 & 0.27 & 5.5 & -1.23 & -3.34 \\
\hline & 14 & n-Propylbenzene & 31 & 36 & 11.85 & 0.25 & 5.5 & -1.25 & -3.63 \\
\hline & 15 & n-Butylbenzene & 32 & 37 & 12.46 & 0.28 & 5.7 & -1.26 & -3.66 \\
\hline \multirow[t]{6}{*}{$N$-ethyl acetamide } & 16 & Benzene & 19 & 21 & 7.25 & 0.29 & 4.8 & -0.59 & -1.31 \\
\hline & 17 & Toluene & 24 & 25 & 7.95 & 0.37 & 5.1 & -1.08 & -2.55 \\
\hline & 18 & Ethylbenzene & 25 & 26 & 8.02 & 0.38 & 5.2 & -1.18 & -2.62 \\
\hline & 19 & n-Propylbenzene & 27 & 28 & 8.32 & 0.40 & 5.3 & -1.2 & -2.92 \\
\hline & 20 & Xylene & 30 & 30 & 8.82 & 0.48 & 5.5 & -1.57 & -3.79 \\
\hline & 21 & Mesytilene & 35 & 36 & 9.56 & 0.59 & 5.8 & -2.06 & -5.03 \\
\hline \multirow[t]{6}{*}{$N$-methyl propanamide } & 28 & Benzene & 19 & 19 & 7.29 & 0.23 & 4.8 & -0.49 & -1.24 \\
\hline & 29 & Toluene & 24 & 23 & 7.98 & 0.28 & 5.1 & -0.98 & -2.48 \\
\hline & 30 & Ethylbenzene & 26 & 24 & 8.22 & 0.32 & 5.2 & -1.08 & -2.55 \\
\hline & 31 & n-Propylbenzene & 28 & 26 & 8.42 & 0.35 & 5.4 & -1.1 & -2.84 \\
\hline & 32 & Xylene & 31 & 29 & 8.84 & 0.38 & 5.6 & -1.47 & -3.72 \\
\hline & 33 & Mesytilene & 36 & 34 & 9.65 & 0.48 & 5.9 & -1.96 & -4.96 \\
\hline \multirow[t]{4}{*}{$N$-n-Butyl propanamide } & 34 & Benzene & 19 & 19 & 7.26 & 0.23 & 4.8 & -0.49 & -1.24 \\
\hline & 35 & Toluene & 24 & 23 & 7.99 & 0.28 & 5.1 & -0.98 & -2.48 \\
\hline & 36 & Ethybenzene & 26 & 24 & 8.26 & 0.32 & 5.2 & -1.08 & -2.55 \\
\hline & 37 & n-Propylbenzene & 28 & 26 & 8.43 & 0.35 & 5.4 & -1.1 & -2.84 \\
\hline \multirow[t]{4}{*}{$N$-Isobutyl propanamide } & 38 & Benzene & 23 & 23 & 8.12 & 0.22 & 4.8 & -0.615 & -2.17 \\
\hline & 39 & Toluene & 29 & 26 & 8.51 & 0.26 & 5.3 & -1.105 & -3.41 \\
\hline & 40 & Ethylbenzene & 30 & 27 & 9.11 & 0.31 & 5.5 & -1.205 & -3.48 \\
\hline & 41 & n-Propylbenzene & 31 & 29 & 9.42 & 0.34 & 5.5 & -1.225 & -3.77 \\
\hline \multirow[t]{4}{*}{$N$-sec-Butyl propanamide } & 42 & Benzene & 21 & 25 & 6.73 & 0.19 & 4.3 & -0.7 & -2.46 \\
\hline & 43 & Toluene & 27 & 28 & 7.26 & 0.22 & 4.8 & -1.19 & -3.7 \\
\hline & 44 & Ethylbenzene & 28 & 28 & 7.88 & 0.24 & 4.9 & -1.29 & -3.77 \\
\hline & 45 & n-Propylbenzene & 29 & 30 & 8.19 & 0.27 & 4.9 & -1.31 & -4.06 \\
\hline \multirow[t]{4}{*}{$N$-t-Butyl propanamide } & 46 & Benzene & 18 & 19 & 6.36 & 0.16 & 3.8 & -0.79 & -2.78 \\
\hline & 47 & Toluene & 23 & 22 & 6.84 & 0.20 & 4.3 & -1.28 & -4.02 \\
\hline & 48 & Ethylbenzene & 25 & 24 & 7.02 & 0.20 & 4.4 & -1.38 & -4.09 \\
\hline & 49 & n-Propylbenzene & 26 & 25 & 7.25 & 0.23 & 4.5 & -1.4 & -4.38 \\
\hline
\end{tabular}

monomer absorbency using Becker's procedure [17]. The enthalpies of hydrogen bonded complex formation $\Delta H$ were calculated using the dependence of the equilibrium constants on temperature.

\section{Data analysis}

The 43 hydrogen bonded complexes are characterized by five spectroscopic parameters and two Taft steric and inductive constants: 1) complex band shift, 
$\Delta v$, 2) half width of complex band, $\left.v_{1 / 2}, 3\right)$ the integrated molar absorption coefficient of complex band, $B, 4)$ the equilibrium constant of hydrogen bonded complex formation $K, 5$ ) the enthalpy of hydrogen bonded complex formation, $\Delta H, 6$ ) sum of Taft electronic coefficients for proton donor and acceptor substituents, $\Sigma \sigma$ and 7) sum of Taft steric coefficients for proton donor and acceptor substituents $\Sigma E s$ [18].

Hierarchical clustering and principal component analysis (PCA) [19] have been used for examination of all measurements.

Hierarchical grouping or cluster analysis involves a number of different classification algorithms that put objects into clusters when one does not have any a priori hypotheses. It displays data in 2D space, qualitatively, in a form of dendograms with similarities among samples. Hierarchical cluster analysis was performed using Euclidean distance and Ward method of linkage.

Principal components analysis (PCA) is a well-known technique for reducing the dimensionality of multivariate data by transforming them into orthogonal principal components (PCs), which are linear combinations of the original variables while preserving most of the variance. Prior to hierarchical clustering and PCA, data were preprocessed using column standardization. This scaling procedure ensures that all the variables have the same weighting in the PC model. After the pretreatment, the appropriately formatted data were analyzed by Statistica 8.0 (StatSoft, Tulsa, USA).

\section{RESULTS AND DISCUSSION}

The correlation coefficients between different hydrogen bond complex parameters obtained by FTIR spectroscopy are presented in Table 2.

The correlation coefficients between the used hydrogen bond parameters confirm that the variables contain similar information. The complex band shift, $\Delta v$, exhibits the highest correlation with all other parameters, whereas the integrated molar absorption coefficient of complex band B exhibits the lowest correlation.

\section{Hierarchical cluster analysis}

In order to evaluate possible classes among samples considered, a clustering method was carried out before
PCA. For the present study, the Euclidean distance and Ward method were used. Figure 1 shows the dendrographic classification of hydrogen bonded complexes and, as it can be seen, three main clusters can be observed.

Cluster A contains all benzene complexes and complexes with short alkyl chains (toluene, ethylbenzene). Cluster B includes 100\% $n$-butyl benzene, xylene and $87.5 \% n$-propylbenzene complexes. The cluster $C$ reflects high similarity between complexes of amides with polymethyl substituted benzenes.

The two main clusters ( $A$ and $B$ ) could be additionally separated into two sub-clusters each forming in this way an entity of four clusters. Subcluster a1 contains dominantly complexes with benzene as the proton acceptor. Subcluster a2 contains complexes of $\mathrm{N}$ sec-butyl and $t$-butyl propanamides. Parts of $N$ - $t$-butyl formamide complexes are grouped in subcluster b1. Subcluster b2 joins a part of $\mathrm{N}$-cyclohexyl formamide complexes.

Main clusters are formed according to proton acceptors, whereas subclusters are formed according to proton donors. The same separation pattern could be obtained even if the equilibrium constant that is often used for complex comparison was removed for the analysis.

\section{Principal component analysis}

PCA was used in order to visualize multivariate data, to identify possible classes and to find relationships among variables. When PCA was applied to the standardized data matrix, two principal components with eigenvalues exceeding one were extracted. The choice of significant number of PC is validated by the estimation of the eigenvalues (only values higher than 1.00 are taken into account). The scree plot is shown in Figure 2.

The scores plot for the first two principal components is shown in Figure 3.

This score graph of first two principal components accurately represents the seven-dimensional original data space since it describes $91.4 \%$ of the total variance, which indicates that the data compression is very efficient. The first principal component, PC1, accounts

Table 2. The correlation coefficients between different hydrogen bond complex parameters

\begin{tabular}{|c|c|c|c|c|c|c|c|}
\hline & $\Delta v$ & $v_{1 / 2}$ & $B$ & $K$ & $\Delta H$ & $\Sigma E s$ & $\Sigma \sigma$ \\
\hline$\Delta v$ & 1.000 & 0.848 & 0.286 & 0.830 & 0.892 & -0.948 & -0.930 \\
\hline$v_{1 / 2}$ & & 1.000 & 0.661 & 0.667 & 0.771 & -0.742 & -0.704 \\
\hline$B$ & & & 1.000 & 0.184 & 0.377 & -0.121 & -0.044 \\
\hline$K$ & & & & 1.000 & 0.852 & -0.838 & -0.734 \\
\hline$\Delta H$ & & & & & 1.000 & -0.767 & -0.699 \\
\hline$\Sigma E s$ & & & & & & 1.000 & -0.978 \\
\hline$\Sigma \sigma$ & & & & & & & 1.000 \\
\hline
\end{tabular}




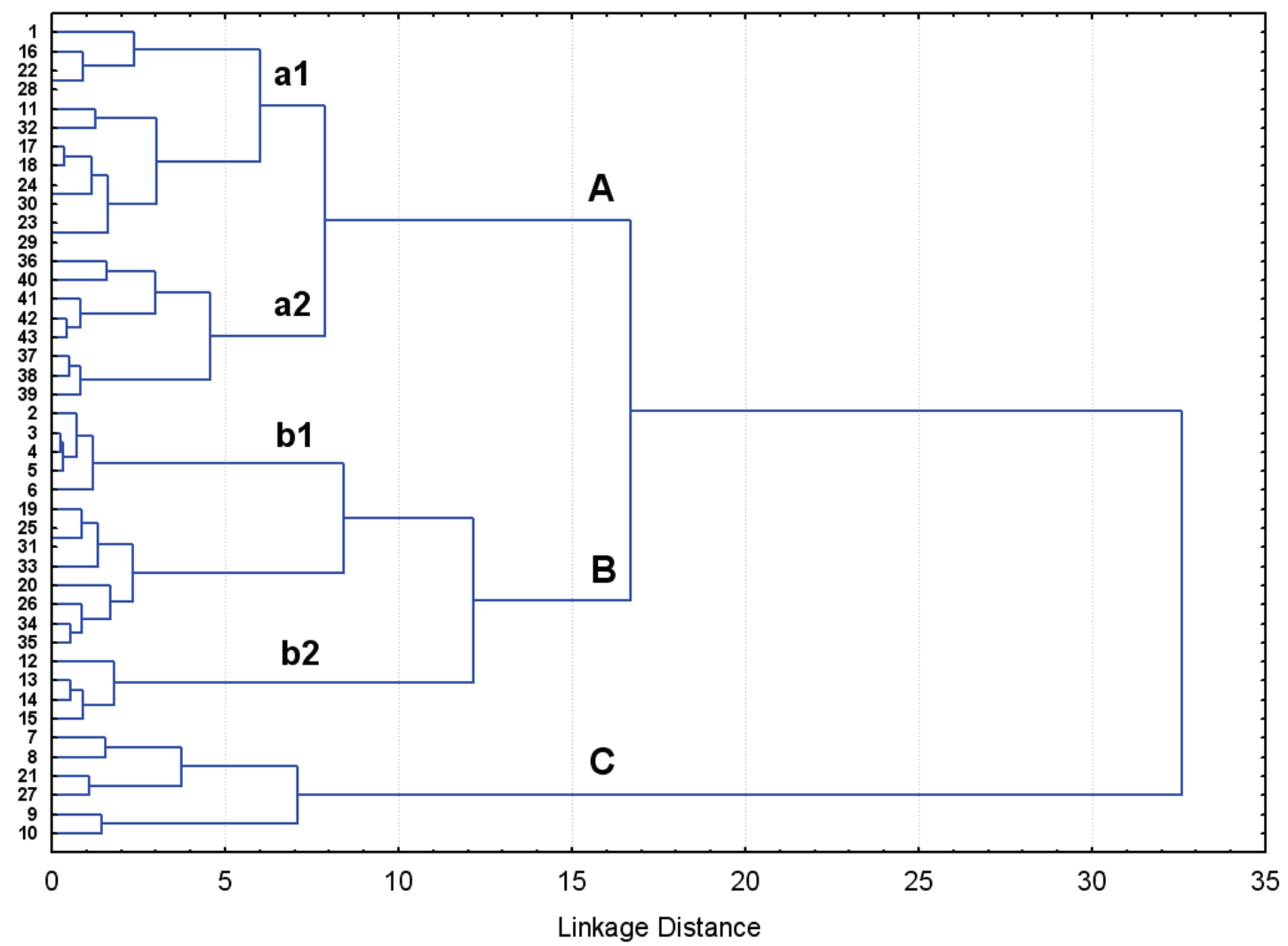

Figure 1. Dendrographic classification of hydrogen bonded complexes using the Euclidean distance and applying the Ward linkage method.

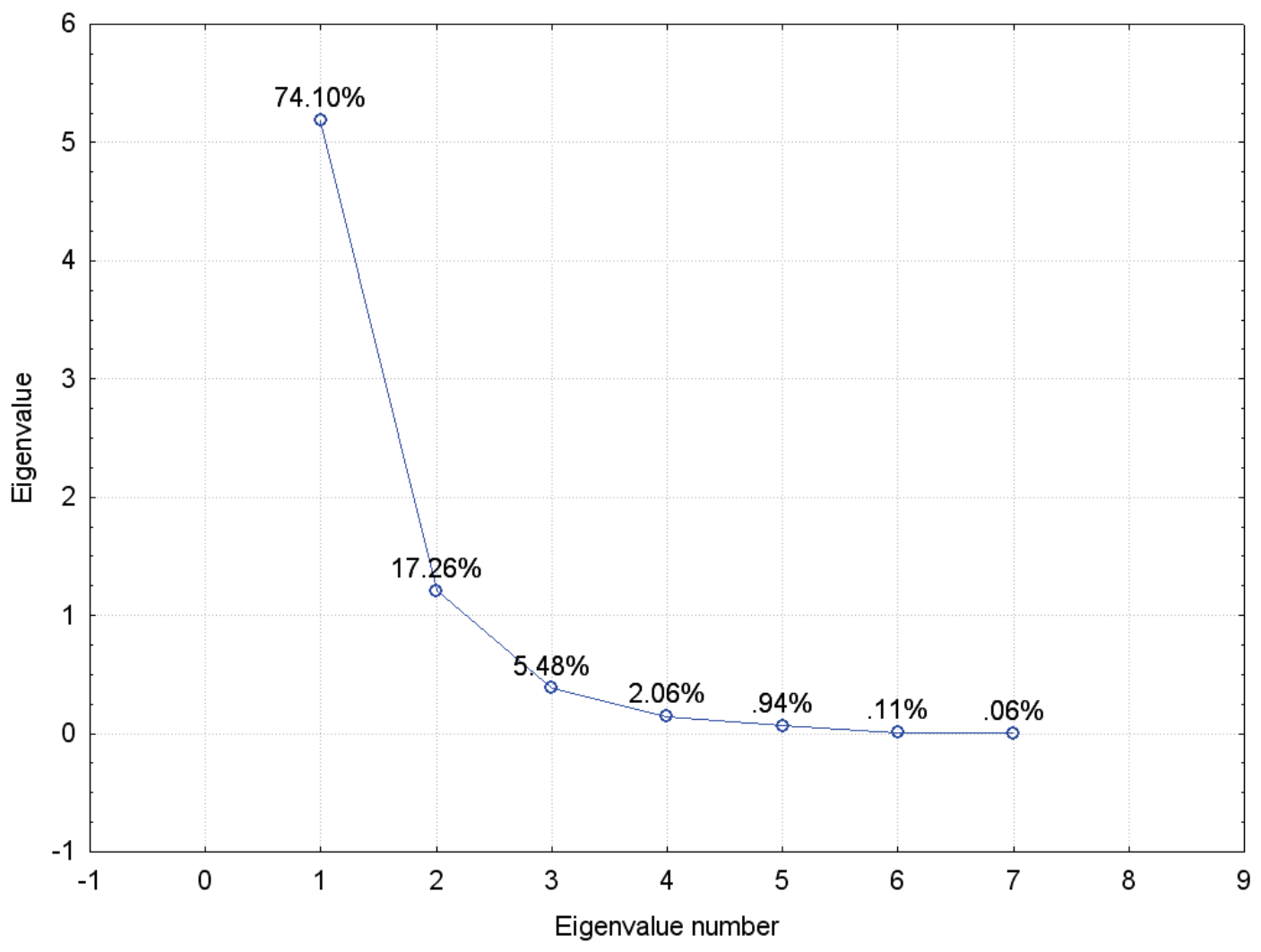

Figure 2. Scree plot for PCA. 


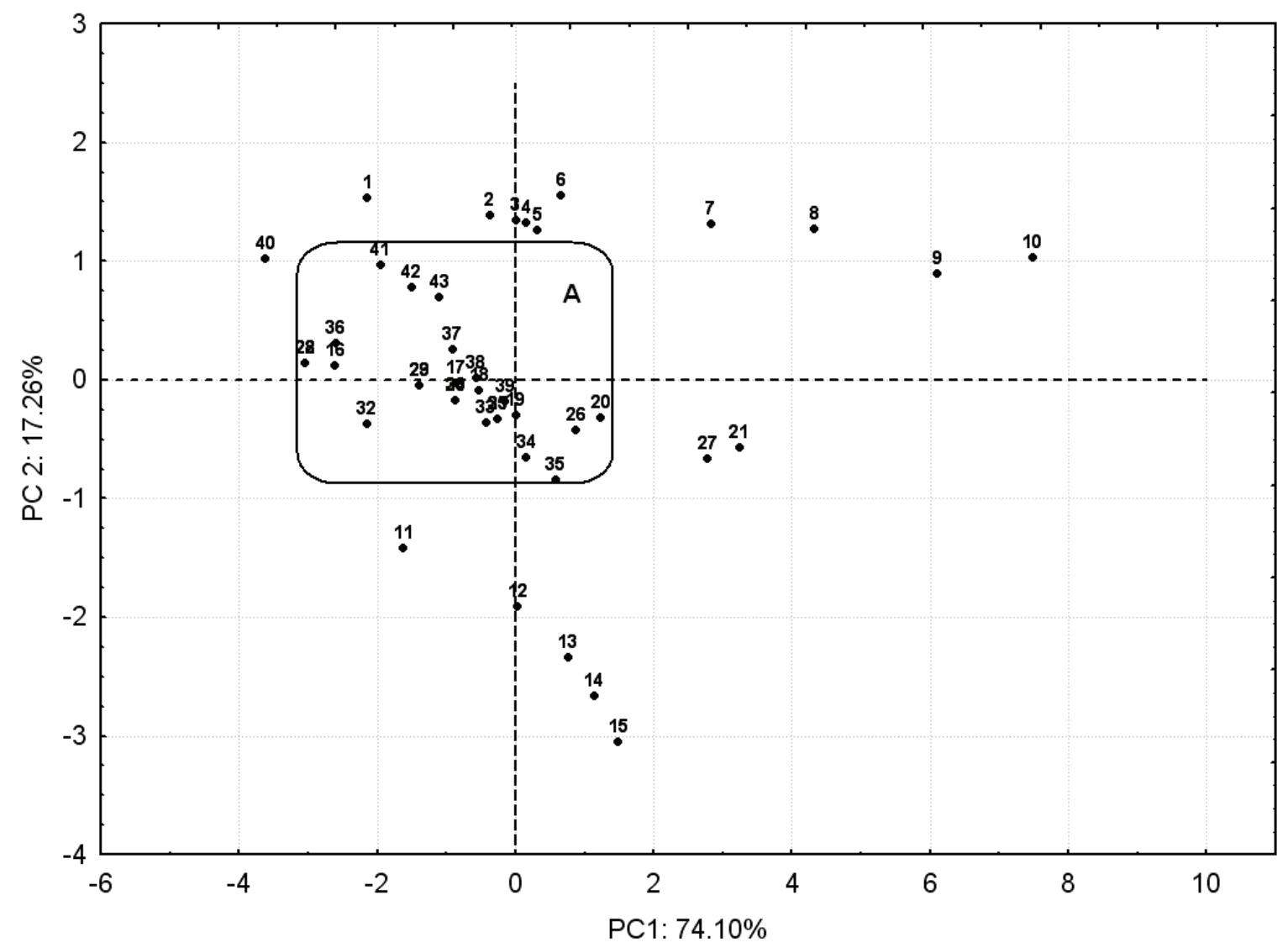

Figure 3. The score plot of the hydrogen bonded complexes in the plane of the first two principal components.

for $74.1 \%$ of the total data variance, whereas the second principal component, PC2, accounts for $17.26 \%$.

The corresponding loading plots (Figure 4) show the parameters responsible for segregation of the complexes. The first two principal components are given by the following equations:

$$
\begin{aligned}
& P C 1=0.432 \Delta v+0.387 v_{1 / 2}+0.159 B+0.387 K+ \\
& +0.398 \Delta H-0.394 \Sigma \sigma-0.414 \Sigma E s \\
& P C 2=0.069 \Delta v-0.351 v_{1 / 2}-0.836 B+0.133 K- \\
& -0.075 \Delta H-0.299 \Sigma \sigma-0.242 \Sigma E s
\end{aligned}
$$

Complexes of $\mathrm{N}$-substituted propionamides and acetamides with monosubstituted benzenes are close together along the first two principal components and form general cluster A. Complexes with polymethyl substituted benzenes (samples 7-10, 21 and 27) are separated along the PC1. Formamide complexes with cyclohexyl (11-15) and with t-butyl (1-6) as N-substituents are well separated from the main cluster according to the second principal component PC2. Within cluster A, $\mathrm{N}$-t-butyl complexes (40-43) are grouped together and separated. A similar separation pattern was obtained by cluster analysis.
Figure 4 shows the distribution and contribution of parameters to the first two principal components. Apart from the molar integral intensity $B$, all parameters significantly contribute to PC1, whereas the molar integral intensity $\mathrm{B}$ contributes most significantly to the second principal component. The second principal component is also strongly associated with the half width of complex band, $v_{1 / 2}$. From the correlation matrix it can be seen that integral intensity, $B$, has a significant correlation only with the half width of the complex band, $v_{1 / 2}$. Parameters $\Delta v, K$ and $\Delta H$ are strongly associated on the loadings graph, which should not be surprising, because these parameters show strong correlation $(\Delta v-\Delta H 0.892, \Delta H-K 0.852, \Delta v-K 0.830)$. Complex band shift $\Delta v$ and Sum of Taft steric coefficients $\Sigma E$ s are almost diametrically opposed, suggesting that they measure opposite properties. High $\Delta v$ corresponds to low $\Sigma E$ s. This relation indicates the importance of steric effects in weak $\mathrm{N}-\mathrm{H} \cdots \pi$ interactions.

The energy and stability of hydrogen bond $\mathrm{N}-\mathrm{H} \cdots \pi$ complexes depends strongly on many factors: acidity of the proton donor, basicity of the proton acceptor, steric and inductive effects on the proton donor and acceptor substituents. Several investigators [20-22] have obtained equilibrium constants for hydrogen bonding 


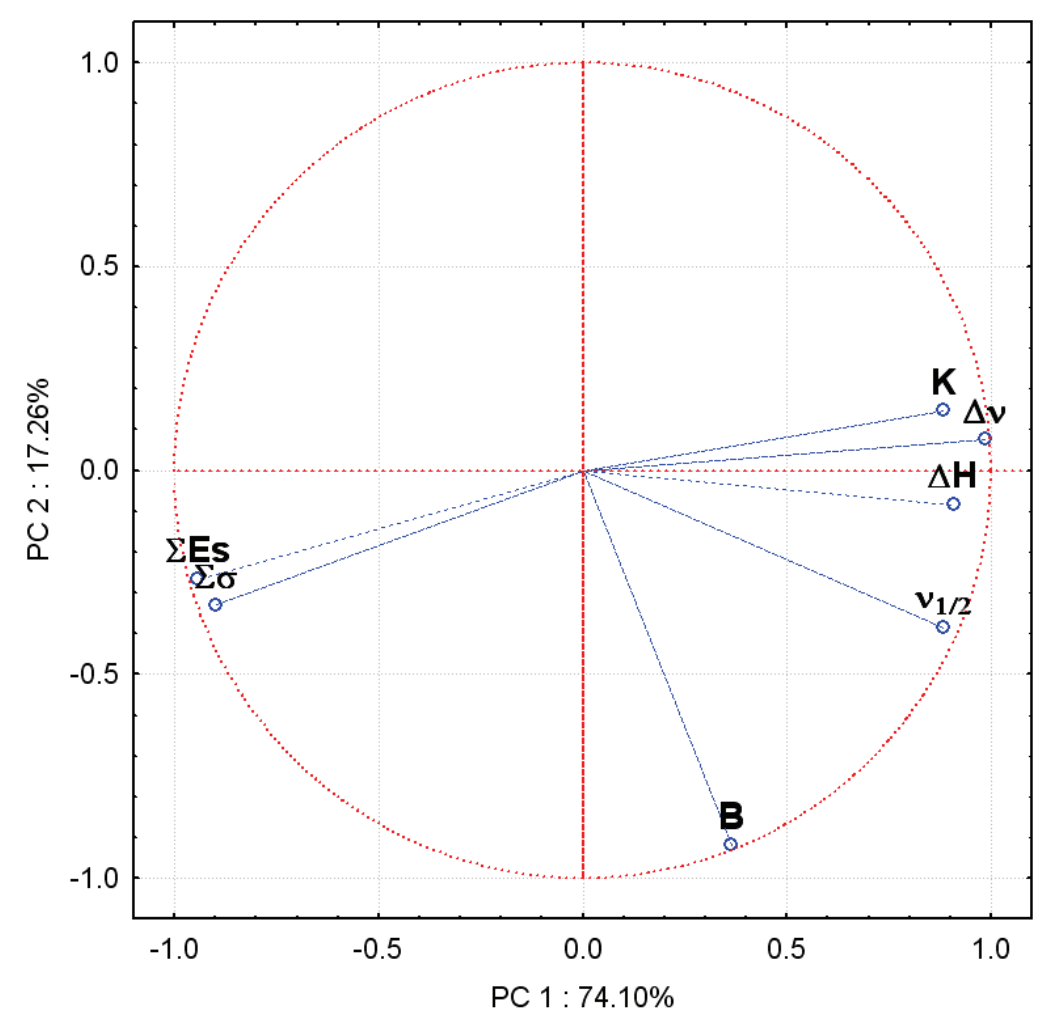

Figure 4. Loading plot of parameters on the first two principal components.

between phenols with various (cyclic and acyclic) ethers and they have established that donor-acceptor interactions are sensitive to both steric and electronic effects.

The main disadvantage of FTIR spectroscopy as a method for examining weak hydrogen bonds is the partial overlapping of monomer and complex bands. Deconvolution of partially overlapped bands is usually complicated, and includes great experimental error determining spectroscopic parameters, especially $B$ and $v_{1 / 2}$. The influence of proton acceptor basicity on complex stability is explicit shown on the score graph. The electron-releasing effect of the methyl substituents increases the electron density in the $\pi$-system [23-25], and as a consequence, the monomer and complex bands are well separated and the spectroscopic parameters can be determined with more accuracy. This fact is responsible for the specific segregating effect in the dendrogram and score plot. Using the spectroscopic parameters of stronger hydrogen-bonded systems with clearly separated bands would give better separation on the score graph and give better insight into the relationships between the parameters in the loading graph.

\section{CONCLUSIONS}

The results of this work have shown that chemometric methods can be used to visualize similarities among hydrogen-bonded complexes according to the spectroscopic and theoretical parameters. It was possible to distinguish $\mathrm{N}-\mathrm{H} \cdots \pi$ complexes according to proton acceptor basicity, since good separation in the dendrogram and the scores plot was obtained. The results obtained in this report are in good agreement with conclusions of other spectroscopic and thermodynamic analysis. Hence, it follows that this could be an important tool to produce a higher level of understanding the hydrogen bonding of secondary amides.

\section{Acknowledgment}

This work was financially supported by the Ministry of Education and Science of the Republic of Serbia (Project No. 172013).

\section{REFERENCES}

[1] V.E. Borisenko, G.Y. Blinkova, L.L. Osipova, Y.A. Zavjalova, Temperature effects on absorption bands $v(\mathrm{NH})$ and thermodynamics of hydrogen-bonded complexes of $\mathrm{NH}$-donors with proton acceptors, J. Mol Liq. 70 (1996) 31-54.

[2] F. Hammami, S. Nasr, M. Oumezzine, R. Cortes, H-bonding in liquid $\mathrm{N}$-methylformamide as studied by X-ray scattering, Biomol. Eng. 19 (2002) 201-205.

[3] L.M. Kuznetsova, V.L. Furer, L.I. Maklakov, Infrared intensities of $\mathrm{N}$-methylacetamide associates, J. Mol. Struct. 380 (1996) 23-29.

[4] R. Zhang, H. Li, Yi.Lei, S. Han, Structures and interactions in $\mathrm{N}$-methylacetamide-water mixtures studied by IR 
spectra and density functional theory, J. Mol. Struct. 693 (2004) 17-25.

[5] Y. Kawashima, R.D. Suenram, E. Hirota, Dynamical structure of peptide molecules: Fourier transform microwave spectroscopy of $\mathrm{N}$-methylpropionamide, J. Mol. Spectr. 219 (2003) 105-118.

[6] G.C. Pimentel, A.L. McCllelan, Hydrogen Bond, W.H. Freeman \& Co.,L ondon, 1960.

[7] G.D. Rose, R. Wolfenden, Hydrogen bonding, hydrophobicity, packing, and protein folding, Annu. Rev. Biophys. Biomol. Struct. 22 (1993) 381-415.

[8] A.D. Nikolić, N.L. Kobilarov, A.N. Brzić, NH $\cdots \pi$ hydrogen bonding: Infrared study of $\mathrm{N}$-cyclohexylformamidearomatic donor systems, J. Mol. Struct. 99 (1983) 179-188 .

[9] A. Nikolić, S. Petrović, D. N. Perišić-Janjić, N.L. Kobilarov, Infrared study of $\mathrm{NH} \cdots \pi$ hydrogen bonding. $N$-tertbutylformamide - aromatic donor systems, J. Mol. Struct. 143 (1986) 329-332.

[10] A.D. Nikolić, M. Tarjani, N. Perišić-Janjić, S. Petrović, Hydrogen bonding of $\mathrm{N}$-monosubstituted amides. IR study of $\mathrm{N}$-ethylacetamide and $\mathrm{N}$-methylpropionamide, J. Mol. Struct. 174 (1988) 129-134.

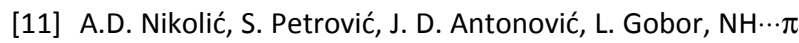
hydrogen bonding: FTIR study of N-butylpropionamidesaromatic donor systems, J. Mol. Struct. 408 (1997) 355-359 .

[12] L. Tasic, R. Rittner, Principal component analysis (PCA) of a-substituent effects on ${ }^{13} \mathrm{C}$ NMR chemical shifts of aliphatic compounds, Ann. Magn. Reson. 3 (2004) 9-11.

[13] L. Tasic, R. Rittner, Principal component analysis of carbon-13 substituent-induced chemical shifts of some unsaturated compound, J. Mol. Struct. 616 (2002) 49-54.

[14] K. C. Weber, K. M. Honorio, S.L.da Silva, R. Mercdante, A.B. da Silva, Selection of quantum chemical descriptors by chemometric methods in the study of antioxidant activity of flavonoid compounds, Int. J. Quantum Chem. 103 (2004) 731-737.

[15] D. Ž. Mijin, S. D. Petrović, N-Alkylation of $N$ - $n$-butylbenzamide, J. Serb. Chem. Soc. 57 (1992) 549-554.

[16] D.G. Antonović, N.D. Stojanović, B.M. Božić, A.D. Nikolić, S.D. Petrović, Synthesis and FTIR spectroscopic study of some N-monosubstituted propanamides, J. Mol. Struct. 408-409 (1997) 421-423.

[17] E.D. Becker, Infrared studies of hydrogen bonding in alcohol-base systems, Spectrochim Acta. 17 (1961) 436$-447$.

[18] R.W. Taft, in: Steric Effects in Organic Chemistry, M.S. Newman (Ed.), J. Wiley \& Sons, New York, 1956, p. 86.

[19] R.G. Brereton, Chemometrics, J Wiley \& Sons, Chichester, 2003.

[20] M. Berthelot, F.Besseau, C. Laurence The hydrogenbond basicity pKHB scale of peroxides and ethers, Eur. J. Org. Chem. 5 (1998) 925-931.

[21] T. lijama, H. Kakiuchi, The relationship between the association constants of phenol with ethers and those of tricholoroacetic acid with ethers: Estimation of association constants of trichloroacetic acid with oxirane, Tetrahedron 35 (1979) 292-302.

[22] L. Bellon, R.W. Taft, J.L.M. Abbound, Structural effects on the reactivity of ethers in donor-acceptor reactions, J. Org. Chem. 45 (1980) 1166-1168.

[23] S. R. Palit, S. Mukherjee, Sadhan K. De, NH $\cdots \pi$ hydrogen bonding, J. Phys. Chem. 75 (1971) 2404-2405.

[24] M.A. Munoz, O. Sama, M. Galan, P. Guardado, C. Carmona, M. Balon, Hydrogen bonding $\mathrm{NH} / \pi$ interactions between betacarboline and methyl benzene derivatives, Spectrochim. Acta, A 57 (2001) 1049-1056.

[25] E.S. Stoyanov, I.V. Stoyanova, C.A. Reed, The Basicity of unsaturated hydrocarbons as probed by hydrogenbond-acceptor ability: Bifurcated $\mathrm{NH}+\cdots \mathrm{p}$ Hydrogen Bonding, Chem. Eur. J. 14 (2008) 7880-7890.

\title{
IZVOD
}

\section{HEMOMETRIJSKA KARAKTERIZACIJA VODONIČNO-VEZANIH KOMPLEKSA SEKUNDARNIH AMIDA I AROMATIČNIH UGLOVODONIKA}

\author{
Branislav Jović ${ }^{1}$, Aleksandar Nikolić ${ }^{1}$, Slobodan Petrović ${ }^{2}$ \\ ${ }^{1}$ Univerzitet u Novom Sadu, Departman za hemiju, Prirodno-matematički fakultet, Novi Sad, Srbija \\ ${ }^{2}$ Univerzitet u Beogradu, Tehnološko-metalurški fakultet, Beograd, Srbija
}

(Naučni rad)

U ovom radu hemometrijski su okarakterisani vodonično vezani kompleksi sekundarnih amida i aromatičnih ugljovodonika. Metodama klaster analize i analizom glavne komponente utvrđene su razlike među $\mathrm{N}-\mathrm{H} \cdots \pi$ kompleksima na osnovu baznosti proton akceptora. Dobijeni rezultati se u dobroj meri slažu sa rezultatima spektroskopskih i termodinamičkih istraživanja.
Ključne reči: Vodonična veza • Sekundarni amidi • Aromatični ugljovodonici • Glavne komponente 